\title{
A COLLECTION OF \\ PAPERS OF ARTHUR WALEY AND BERYL DE ZOETE
}

\author{
BY FRANCIS A. JOHNS \\ Bibliographer, Rutgers University Library
}

7 HE fact that the Library, thanks to the Duncan D. Sutphen and George V. N. Baldwin bequests, recently acquired a collection of books and papers formerly belonging to Arthur Waley and Beryl de Zoete has prompted some requests for a listing of material. As it is not at present possible to produce a detailed inventory, this necessarily brief general description may be helpful and indicative to those interested.

Waley's work in the field of Japanese and Chinese studies is too extensive and well known to need comment here. He began about the time of the first World War and between then and I 964 he produced some forty books as well as over seventy-five articles. However, one comes upon other writings of his on very diverse subjects in the periodicals of the time. Articles on history, art, anthropology, the ballet and skiing, even a translation from the Apocalypse, and mention of his version of Hroswitha's Callimachus, which was performed at the Haymarket Theater in I 920 . But poetry has been a lifelong interest ever since his undergraduate days. At King's College, Cambridge, where he was a year behind his friend Rupert Brooke, also a Rugbeian, Waley read Classics.

Waley knew Beryl de Zoete, who died in 1962, for nearly fifty years. A pupil of Dalcroze, she wrote books on dancing in Bali, India and Ceylon, which are basic and authoritative works. Her linguistic gifts were extraordinary. She translated both from and into German: Waley himself printed one of her translations from Japanese, and her version of Svevo's Una burla riuscita, published by the Hogarth Press in I929, seems to mark his first appearance in English translation in book form. Waley published a small collection of her essays in 1963 in The Thunder and the Freshness, to which he contributed a short preface with some biographical information. 
Waley's oriental library is now in Durham University, England. The material at Rutgers came as a result of his moving from Gordon Square to Great James Street nearby in Bloomsbury: it is in no sense an organized collection, but rather an accumulated mass of papers. However, because of the large number of people the two friends knew, the correspondence, letters and notebooks give the reader some interesting sidelights on literary life in England between the wars. It was Osbert Sitwell who said that, of anyone he knows, Arthur Waley has perhaps the greatest range of friendship, "extending from dons and savants to spiritualists and members of Parliament, from his own kind, poets, painters, musicians, to those who practice their obsolete Eskimo tricks in winter on the topmost slopes of mountains." Most of Bloomsbury knew Waley but he did not limit himself to any one group; he knew the Vorticists too. One finds letters from the Sitwells, Mary MacCarthy, Bernard Berenson, Gerald Brenan, Harold Acton and John Lehmann, to mention some. Waley's own manuscripts extend right into the I960's.

There are some three thousand books, mostly in Western European languages ranging from sinology, archeology and anthropology, grammars, language manuals and painting to modern English and Italian literature. Over a third are either inscribed to Arthur Waley or Miss de Zoete, or have their annotations.

The manuscript material occupies eight 5 × I 5 x Io" manuscript boxes and comprises a number of manuscripts of books and articles with corrected proofs. It includes some apparently unpublished works, such as short stories seemingly dating from Waley's undergraduate days and some translations of Japanese poems which were written during the revolutionary period from i 860 to 1868 . The distribution list of Waley's first separately published work Chinese Poems, I9I 6 shows that it was destined for such people as Lowes Dickinson, F. W. Bateson, Ezra Pound, Walter Sickert, Logan Pearsall Smith, Clive Bell, Laurence Binyon, Helen Saunders, Charles Ricketts, Roger Fry, Dora Carrington, Sydney Cockerell, Iris Barry, Bertrand Russell, T. S. Eliot, Leonard Woolf and W. B. Yeats, among others. There are holograph poems by Edith Sitwell and the Portuguese poet, Alberto de Lacerda, whose work Waley also translated into English. 
A further six boxes of Miss de Zoete's letters and manuscripts, in a hand becoming progressively more difficult to read, contain chiefly materials on dancing, both classic and folk, eastern and western. There are some of her diaries as well as many photographs, pamphlets and programs.

The Department of Special Collections has available a twenty page typewritten preliminary inventory of the books and papers.

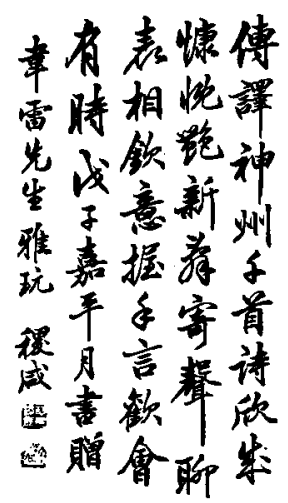

Honorific Scroll, signed Shee-hsien presented to Arthur Waley in 1948. 